Article

\title{
Kinetic Resolution in Transannular Morita-Baylis-Hillman Reaction: An Approximation to the Synthesis of Sesquiterpenes from Guaiane Family
}

\author{
Raquel Mato, Rubén Manzano ${ }^{\dagger}$, Efraím Reyes *(D), Liher Prieto, Uxue Uria, Luisa Carrillo and Jose L. Vicario *
}

check for updates

Citation: Mato, R.; Manzano, R.; Reyes, E.; Prieto, L.; Uria, U.; Carrillo, L.; Vicario, J.L. Kinetic Resolution in Transannular Morita-Baylis-Hillman Reaction: An Approximation to the Synthesis of Sesquiterpenes from

Guaiane Family. Catalysts 2022, 12, 67 . https://doi.org/10.3390/catal12010067

Academic Editors: Cristina Trujillo and Takeshi Ohkuma

Received: 24 November 2021

Accepted: 5 January 2022

Published: 8 January 2022

Publisher's Note: MDPI stays neutral with regard to jurisdictional claims in published maps and institutional affiliations.

Copyright: (C) 2022 by the authors. Licensee MDPI, Basel, Switzerland. This article is an open access article distributed under the terms and conditions of the Creative Commons Attribution (CC BY) license (https:// creativecommons.org/licenses/by/ $4.0 /)$.
Department of Organic and Inorganic Chemistry, University of the Basque Country (UPV/EHU), P.O. Box 644, 48080 Bilbao, Spain; fam.mat.sant@gmail.com (R.M.); ruben.manzano@uah.es (R.M.); liher.prieto@ehu.es (L.P.); uxue.uria@ehu.es (U.U.); marisa.carrillo@ehu.es (L.C.)

* Correspondence: efraim.reyes@ehu.es (E.R.); joseluis.vicario@ehu.es (J.L.V.)

+ Current Address: Department of Organic and Inorganic Chemistry, Institute of Chemical Research Andrés Manuel del Río (IQAR), University of Alcala, 28805 Alcalá de Henares, Spain.

\begin{abstract}
An approximation to the synthesis of several sesquiterpenes from the Guaiane family is described in which the core structure was obtained through a transannular Morita-Baylis-Hillman reaction performed under kinetic resolution. Several manipulations of the obtained $\mathrm{MBH}$ adduct have been carried out directed towards the total synthesis of $\gamma$-Gurjunene, to the formal synthesis of Clavukerin A, to the synthesis of a non-natural isomer of isoguaiane and to the synthesis of an advanced intermediate in the total synthesis of Palustrol.
\end{abstract}

Keywords: Morita-Baylis-Hillman; transannular; kinetic resolution; sesquiterpene; phosphine; catalysis; natural product; Palustrol; Clavukerin A; guaiene

\section{Introduction}

Polycyclic structures are common motifs present in the structural core of many natural products [1]. The biological activity exhibited by some of these compounds, has inspired the development of many pharmaceutically active compounds and therefore it has attracted the attention of the synthetic community in order to develop new efficient approaches for their preparation [2]. In particular, the lack of supply or isolation difficulties of such polycyclic bioactive compounds, have brought to light the need for new strategies for the stereocontrolled construction of polycyclic scaffolds, in view of the key role played by the three-dimensional arrangement of these molecules with respect to the interaction with the corresponding biological receptor that accounts for the physiological response [3]. In this sense, synthetic chemists have contributed to this field not only by the development of synthetic routes to access biologically active compounds, but also by providing critical information regarding the structure-activity relationship [4]. In the field of natural products, the hydroazulene bicyclic system is a substructure commonly present as part of the structural core of different families of sesquiterpenoids, such as aromadendrane or guaiane families, both characterized by the presence of a cyclopropane unit or a lateral three carbon atom chain attached to the seven-membered ring moiety respectively (Figure 1) [5]. 


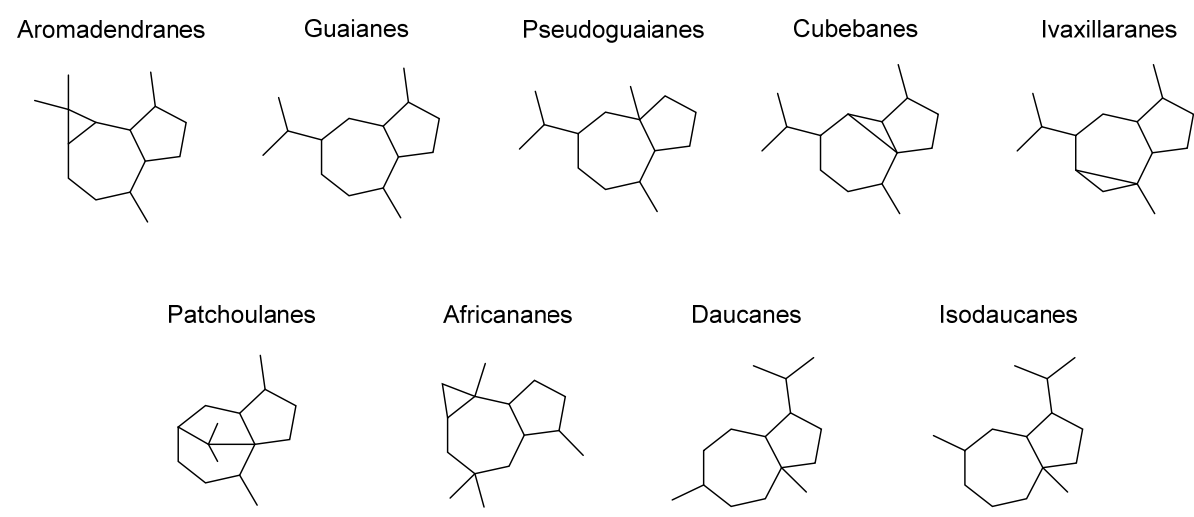

Figure 1. Sesquiterpenoid families containing hydroazulene core.

Although, most of these natural products have been commonly isolated from essential oils extracted from different plants and trees, in the last years marine organisms have arisen as a surprisingly prolific source of these biologically active sesquiterpenoids [6-10]. Despite this natural availability, some sesquiterpenoids still remain relatively inaccessible, pinpointing the necessity for the development of efficient synthetic routes. In this sense, the enantioselective transannular Morita-Baylis-Hillman reaction catalyzed by chiral bifunctional phosphines developed by us (Scheme 1a), [11] has demonstrated to be a suitable strategy to access the bicyclo[5.3.0]decane scaffold, a structural core found in different sesquiterpenoids such as Palustrol, Clavukerin A, $\gamma$ gurjunene or guaia-5(6)-en-11-ol among others (Scheme 1b).

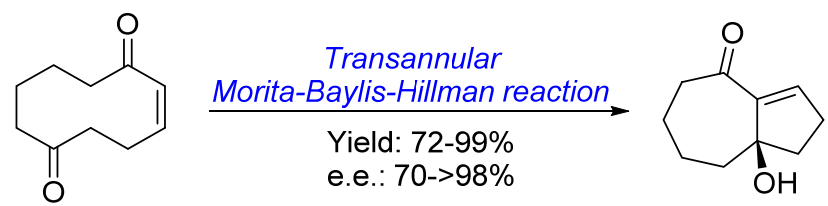

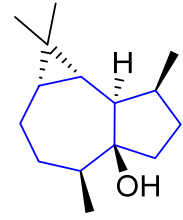

(+)-Palustrol<smiles>CC1=C2C=CCC[C@H](C)C2CC1</smiles>

Clavukerin A<smiles>CC1=C2C=CCC[C@H](C)[C@H]2CC1</smiles>

Isoclavukerin A

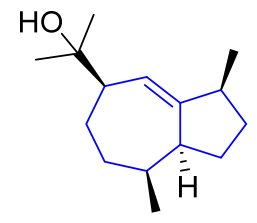

Guaia-5(6)-en-11-ol

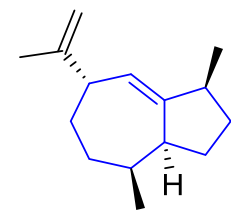

$(-)-\gamma-$ Gurjunene

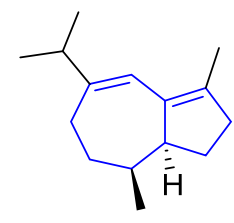

Isoguaiene (b)

Scheme 1. (a) Enantioselective Morita-Baylis-Hillman reaction developed in our group; (b) Representative examples of sesquiterpenoids containing bicyclo[5.3.0]decane scaffold.

Although huge progresses have been made in this field towards the synthesis of some of these compounds, most of the reported approaches rely on the chiral pool methodology, being in some cases necessary the employment of related sesquiterpenoids as starting materials [12-27]. Considering that the mentioned catalytic enantioselective transannular Morita-Baylis-Hillman reaction developed in our group could be employed as key step in the total synthesis of some of these sesquiterpenoids, we wish to present herein different approaches to several of these compounds using this reaction as key step. In this regard, as all the synthetic targets contain a methyl group at C-8 position, we envisioned that a racemic substrate bearing a methyl group such as $\mathbf{1}$ could be employed as starting material. A kinetic resolution process (KR) for the generation of the enantiopure adduct 2 could be employed and being this the starting material of the abovementioned sesquiterpenoids (Scheme 2). 


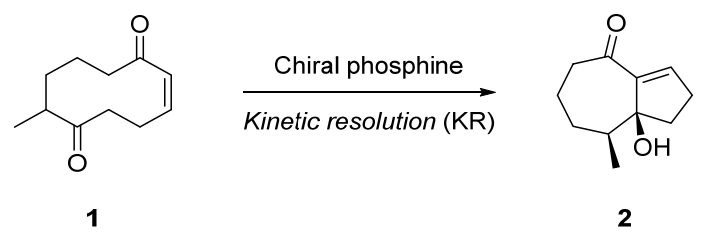

Scheme 2. Projected kinetic resolution through catalytic enantioselective Morita-Baylis-Hillman reaction.

\section{Results and Discussion}

\subsection{Transannular Kinetic Resolution}

We proceeded with the study of the key kinetic resolution step. In this sense, preliminary experiments were carried out by subjecting racemic substrate 1 to the previously optimized conditions for the transannular Morita-Baylis-Hillman process using a chiral phosphine as catalyst (Scheme 3). The reaction was monitored by TLC and, after $7 \mathrm{~h}$, full conversion of the starting material was observed. Under these conditions, adduct 2 was isolated in excellent yield and as a 5:1 mixture of diastereomers, albeit low enantiomeric excess was obtained for the major diastereomer. However, when the analogous reaction was quenched after one hour, adduct 2 could be isolated in $50 \%$ yield as a mixture of diastereomers, determining $70 \%$ e.e. for the major diastereomer and $55 \%$ e.e. for the minor diastereomer.

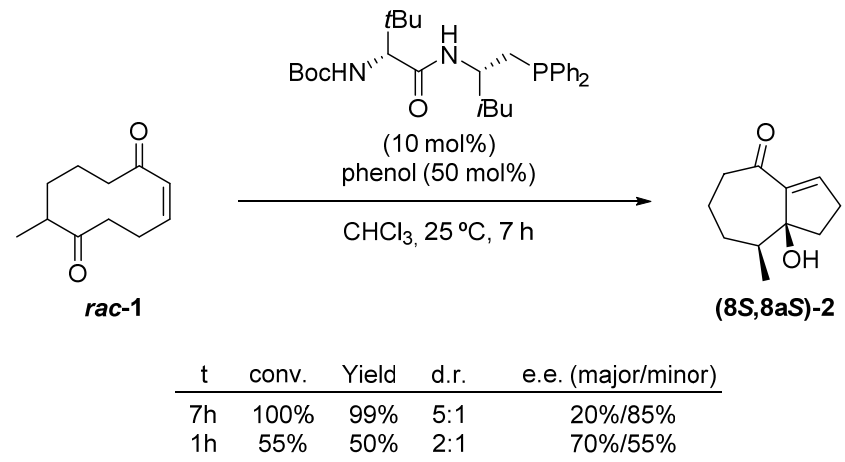

Scheme 3. Preliminary results for the transannular Morita-Baylis-Hillman reaction.

In view of these preliminary results, we decided to carry out a set of reactions under the same experimental conditions, in order to evaluate the dependence of e.e. and d.r. with conversion. However, NMR analysis of crude reaction mixtures showed that the reaction was continuing after work-up due to the presence of all reactive species together with the catalyst in the crude mixture. For this reason, an appropriate method was necessary in order to quench the reaction at the desired time. This method should deactivate the catalyst without affecting either the product of the reaction or the unreacted starting material. In this sense, a work-up in which the phosphine is oxidized to the corresponding phosphine oxide emerged as a suitable strategy. Based on literature precedents [28-32], different oxidizing reagents were surveyed such as peracetic acid, $m$-chloroperbenzoic acid (MCPBA) and hydrogen peroxide. Catalyst oxidation could be easily followed by ${ }^{31} \mathrm{P}-\mathrm{NMR}$, due to the significant shift of the NMR signal that takes place, being around -25 ppm for active catalyst whilst shifts to +30 ppm for corresponding phosphine oxide. After a survey, hydrogen peroxide was chosen as the best option as it provided immediate full deactivation of the catalyst with no side product formation.

Once we found an appropriate experimental procedure for this purpose, we applied the previously optimized conditions for the enantioselective transannular process to a series of identical reactions (Table 1). However, despite different reaction times were evaluated (entries 1-4), none of them provided satisfactory results, achieving a 39\% yield of the desired product, with a d.r. of $15: 1$ and $88 \%$ e.e. for the major diastereoisomers as best results when the reaction was quenched after 50 min (entry 3). Alternatively, when the solvent 
was changed from chloroform to carbon tetrachloride, a significant increase in reaction rate was observed, which allowed us to lower the temperature to $5{ }^{\circ} \mathrm{C}$ (entry 5). Under these conditions, after 20 min adduct 2 was isolated in $46 \%$ yield as a single diastereomer $(>20: 1)$ and with excellent enantioselectivity. At this point, it was decided to scale up the reaction to $0.8 \mathrm{mmol}$ of $\mathbf{1}$ before facing a more comprehensive evaluation of the reaction time parameter (entry 6). Following this methodology, we were able to determine that the reaction should be quenched after $30 \mathrm{~min}$ to access adduct $(\mathbf{8 S}, \mathbf{8 a S})$-2 as a single diastereomer $(>20: 1)$ in good yield (42\%) and high enantiomeric excess $(90 \%)$. Further recrystallization in hexane increased the enantiopurity of adduct $(8 S, 8 \mathrm{aS})-2$ up to a $98 \%$ e.e.

Table 1. Preliminary kinetic resolution studies ${ }^{1}$.

\begin{tabular}{|c|c|c|c|c|c|c|c|}
\hline Entry & Solvent & $\mathrm{T}\left({ }^{\circ} \mathrm{C}\right)$ & Time (min) & Recovered 1 (\%) & e.e. $1(\%)^{2}$ & Yield $2(\%)$ & e.e. $2(\%)^{2}$ \\
\hline 1 & $\mathrm{CHCl}_{3}$ & 25 & 40 & 61 & 50 & 35 & 88 \\
\hline 2 & $\mathrm{CHCl}_{3}$ & 25 & 45 & 62 & 54 & 37 & 88 \\
\hline 3 & $\mathrm{CHCl}_{3}$ & 25 & 50 & 57 & 54 & 39 & 88 \\
\hline 4 & $\mathrm{CHCl}_{3}$ & 25 & 55 & 50 & 66 & 42 & 86 \\
\hline 5 & $\mathrm{CCl}_{4}$ & 5 & 20 & - & - & 46 & 90 \\
\hline $6^{3}$ & $\mathrm{CCl}_{4}$ & 5 & 30 & 56 & 76 & 42 & 90 \\
\hline
\end{tabular}

${ }^{1}$ Reactions performed at $0.1 \mathrm{mmol}$ scale employing $10 \mathrm{~mol} \%$ of catalyst and $50 \mathrm{~mol} \%$ of phenol in $\mathrm{CHCl}_{3}$ $(0.1 \mathrm{mmol} / \mathrm{mL})$ at room temperature. Diastereomeric ratio for product 2 was $>15: 1$ in all the cases. Yields refer to isolated pure products. ${ }^{2}$ Calculated by HPLC on chiral stationary phase. ${ }^{3}$ Reactions performed at $0.8 \mathrm{mmol}$ scale.

The absolute configuration of adduct $(\mathbf{8 S}, \mathbf{8 a S})-\mathbf{2}$ and of the resolved unreacted starting material $(\boldsymbol{R})-\mathbf{1}$ could be determined by single crystal X-ray diffraction (Figure 2) [11].<smiles>CC1CCCC(=O)C2=CCCC21O</smiles>

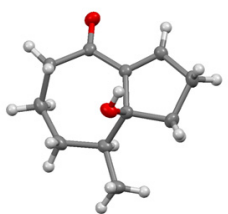

$(8 S, 8 \mathrm{aS})-2$

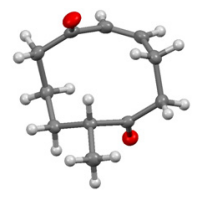<smiles>C[C@H]1CCCC(=O)C=CCCC1=O</smiles>

$(R)-1$

Figure 2. Stereostructures for bicyclic (8S,8aS)-2 and unreacted starting material (R)-1.

\subsection{Preparation of an Advanced Intermediate in the Synthesis of Palustrol}

Once we found efficient experimental conditions for the synthesis of adduct $(8 S, 8 \mathbf{a S})$-2, we continued with the planned strategy for the synthesis of (+)-Palustrol. As shown in Scheme 4 , the cyclopropane moiety was proposed to be constructed by cyclopropanation of an alkene, which could be as well generated by reduction of the corresponding ketone and subsequent elimination. The methyl group at $\mathrm{C}-4$ was proposed to arise from a conjugate addition across the Morita-Baylis-Hillman bicyclic adduct.

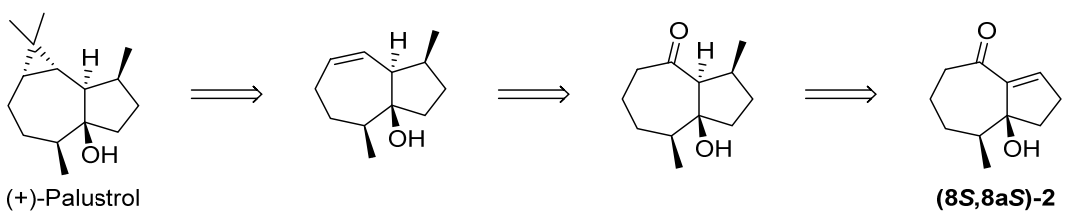

Scheme 4. Retrosynthetic analysis for the synthesis of (+)-Palustrol starting from (8S,8aS)-2.

First of all [11], the protection of the alcohol moiety had to be carried out in order to prevent any interference of this functional group in the subsequent chemical transformations. Unfortunately, this protection resulted as much more challenging than expected, due to either the steric hindrance and/or the allylic nature of this alcohol. Substrate 2 
remained unreactive under several protection conditions tested, such as acetylation, benzylation or methoxymethyl acetal formation. Additionally, common procedures for the introduction of silyl protecting groups using the corresponding silyl chlorides did not afford the protected product [33,34], while more reactive reagents such as silyl triflates or higher temperatures produced decomposition of the starting material. Fortunately, when TMS Imidazole was employed as trimethylsilyl source [35], product 3 could be isolated in 53\% yield (Scheme 5). Analogous procedures for bulkier silyl protecting groups did not provide the corresponding protected products. Next, we proceeded with the projected conjugate addition of $\mathrm{Me}_{2} \mathrm{CuLi}$ to the $\alpha, \beta$ unsaturated system. Unfortunately, after the conjugate addition reaction, the resulting product turned out to be extremely unstable, being necessary to trap the enolate intermediate as the corresponding silyl enol ether. In this way, the preformed Gilman reagent was added at $-78^{\circ} \mathrm{C}$ over adduct 3 , followed by the addition of TMSCl and $\mathrm{NEt}_{3}$ [36-38]. The resulting silyl enol ether was isolated and subjected to DDQ-mediated oxidation to produce compound 6 in very low yields. On the other hand, in situ bromination of silyl enol ether intermediate 4 afforded compound $\mathbf{5}$ as a single diastereomer in $75 \%$ yield over two steps [39]. Next, base-promoted elimination using a literature procedure $\left(\mathrm{Li}_{2} \mathrm{CO}_{3}, \mathrm{LiBr}\right.$ in $\mathrm{DMF}$ at high temperature) converted 5 into 6 in good overall yield [40-42]. This elimination step turned out to be quite sensitive to concentration, resulting in complex product mixtures when concentrated conditions were employed. Fortunately, high diluted conditions $(0.01 \mathrm{M})$ as applied by Baran et al. [43] significantly improved the performance of the reaction affording product 6 in $68 \%$ yield. It should be mentioned that it was required to increase the temperature to $130{ }^{\circ} \mathrm{C}$ to promote the reaction, compared to the $60^{\circ} \mathrm{C}$ used in the literature procedure.

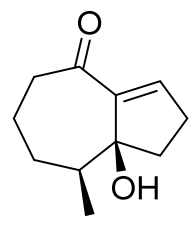

2

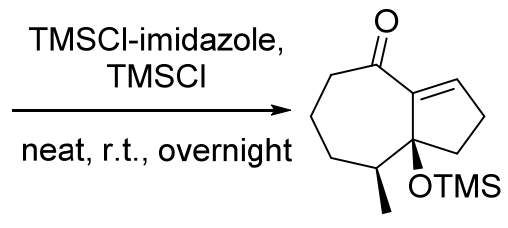

Yield: $53 \%$

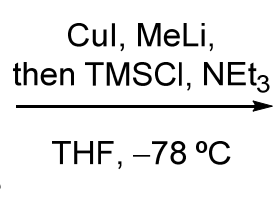

3

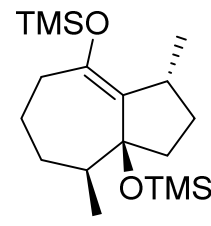

4

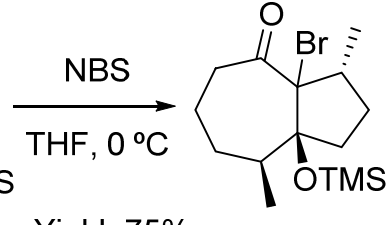

Yield: $75 \%$

(2 steps from 3 )
5

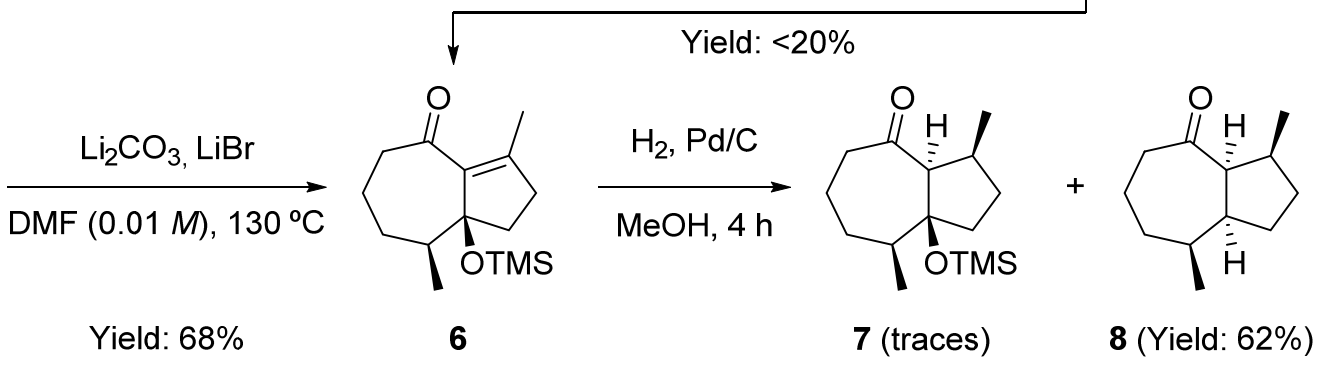

Scheme 5. Synthesis of compound 8 [11].

At this point, adduct 6 was subjected to standard hydrogenation conditions $\left(\mathrm{H}_{2}, \mathrm{Pd} / \mathrm{C}\right.$, $\mathrm{MeOH}$ ) in order to afford product 7. However, in spite of the expected hydrogenated product, compound $\mathbf{8}$ was obtained, in which trimethylsilyloxy group had been lost. The formation of this product was attributed to the reduction of the C-C double bond, as well as concomitant cleavage of silyl protecting group [44] and subsequent spontaneous elimination of the alcohol and second hydrogenation of the resulting product. In any case, after $4 \mathrm{~h}$ of reaction time, full consumption of the starting material was observed by TLC, allowing the isolation of adduct 8 in $62 \%$ yield by flash column chromatography.

The relative configuration of the stereocenters in the molecule could be determined by X-ray diffraction of the corresponding hydrazone 9 (Figure 3). It should be mentioned that the absolute configuration at $\mathrm{C}-3 \mathrm{a}$ in compound $\left(3 S^{*}, 3 \mathrm{a} S^{*}, 8 S^{*}, 8 \mathrm{a} S^{*}\right)-8$ is thought to be opposite to that determined for hydrazone $\left(3 S^{*}, 3 a R^{*}, 8 S^{*}, 8 a S^{*}\right)-9$ (CCDC 2118404), taking 
into account that catalytic hydrogenation is expected to take place through syn addition. Epimerization at $\alpha$ position to carbonyl is believed to occur under hydrazone formation conditions ( $\mathrm{TsNHNH} 2, \mathrm{EtOH}, \mathrm{HOAc}, \mathrm{H}_{2} \mathrm{SO}_{4}$ cat., r.t.).
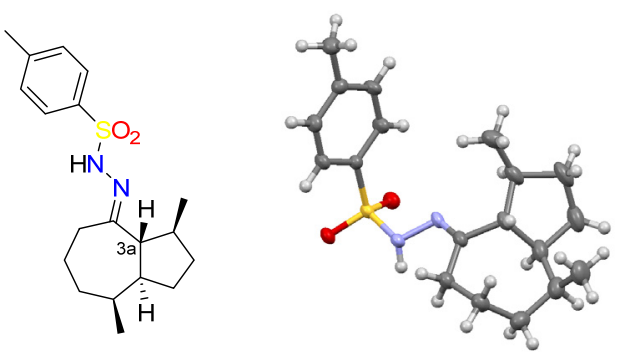

$(3 S, 3 a R, 8 S, 8 a S)-9$

Figure 3. Stereostructure for bicyclic $\left(3 S^{*}, 3 \mathrm{a} R^{*}, 8 S^{*}, 8 \mathrm{a} S^{*}\right)-9$.

At this point, and in order to overcome the undesired deoxygenation, different reported methodologies for conjugate reduction using hydrides were tested. Adduct 6 remained unreactive when exposed to stoichiometric amounts of $\left[\left(\mathrm{Ph}_{3} \mathrm{P}\right) \mathrm{CuH}\right]_{6}$, commonly known as Stryker reagent $[45,46]$. Modification of classical conditions (benzene, r.t.) by increasing the temperature led to complex mixtures of products or complete decomposition of the starting material without observing, in any case, detectable amounts of the desired product. The use of other reported efficient catalytic systems for the conjugate reduction of enones, such as $\mathrm{Et}_{3} \mathrm{SiH} /\left[\mathrm{RhCl}\left(\mathrm{PPh}_{3}\right)_{3}\right]$ or $\mathrm{PhMeSiH} / \mathrm{CuCl},[47,48]$ did not afford the desired product. After several attempts, the discouraging results obtained led us to discard the present synthetic strategy.

\subsection{Formal Total Synthesis of Clavukerin A}

As hydrogenation of compound 6 led to the loss of the alcohol moiety present in the molecule, which prevented us from accessing (+)-Palustrol, we decided to accomplish the synthesis of $(-)$-Clavukerin $A$, as it should be accessed from adduct 8 . As shown in Scheme 6 a carbonyl reduction/elimination was proposed for the final construction of the diene system, from a bicyclic $\alpha, \beta$-unsaturated ketone, which could be accessed from the aforementioned compound 8 .

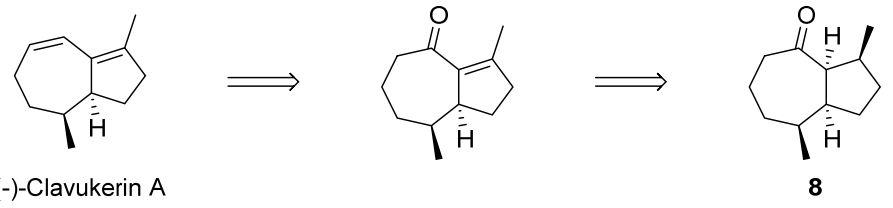

Scheme 6. Retrosynthetic analysis for the synthesis of (-)-Clavukerin A starting from 8.

Our initial attempts were directed to restore the $\alpha, \beta$-unsaturated system in the molecule leading to an enone intermediate, whose transformation into (-)-Clavukerin A has already been described in the literature. In order to achieve this objective, we considered several strategies. First of all, compound $\mathbf{8}$ was transformed into the corresponding silyl enol ether $10[49,50]$ and directly exposed to phenylselenyl chloride in $\mathrm{Et}_{2} \mathrm{O}$ at $-78{ }^{\circ} \mathrm{C}$, affording selenide $\mathbf{1 1}$ as a single diastereomer, presumably due to the formation of the new C-Se bond through the less hindered face of the silyl enol ether (Scheme 7). Next, adduct 11 was subjected to standard conditions for the oxidation to selenoxide and in situ elimination [51,52]. Unfortunately, when MCPBA was employed as oxidant in dichloromethane at $-78{ }^{\circ} \mathrm{C}$, a 2:1 mixture of regioisomers was obtained and NMR analysis (see Supplementary Materials) allowed us to identify these products as regioisomeric $\alpha, \beta$-unsaturated ketones 12 and 13, being the undesired product 13 formed as the main product. The use of $\mathrm{H}_{2} \mathrm{O}_{2}$ as an alternative oxidant did not provide any improvement on the outcome of the 
reaction, affording products $\mathbf{1 2}$ and $\mathbf{1 3}$ in a similar ratio. The observed lack of selectivity was attributed to the cis orientation of both hydrogens in the two $\beta$ positions with respect to the selenide. As selenide-mediated eliminations are described to take place through a syn arrangement [53-55], this would imply that elimination could take place in both positions. Although it was expected that $\beta$ hydrogen in the cyclopentane ring would be more accessible than the $\beta$ hydrogen in the fused system, experimental observations showed a preferred formation of product 13 .

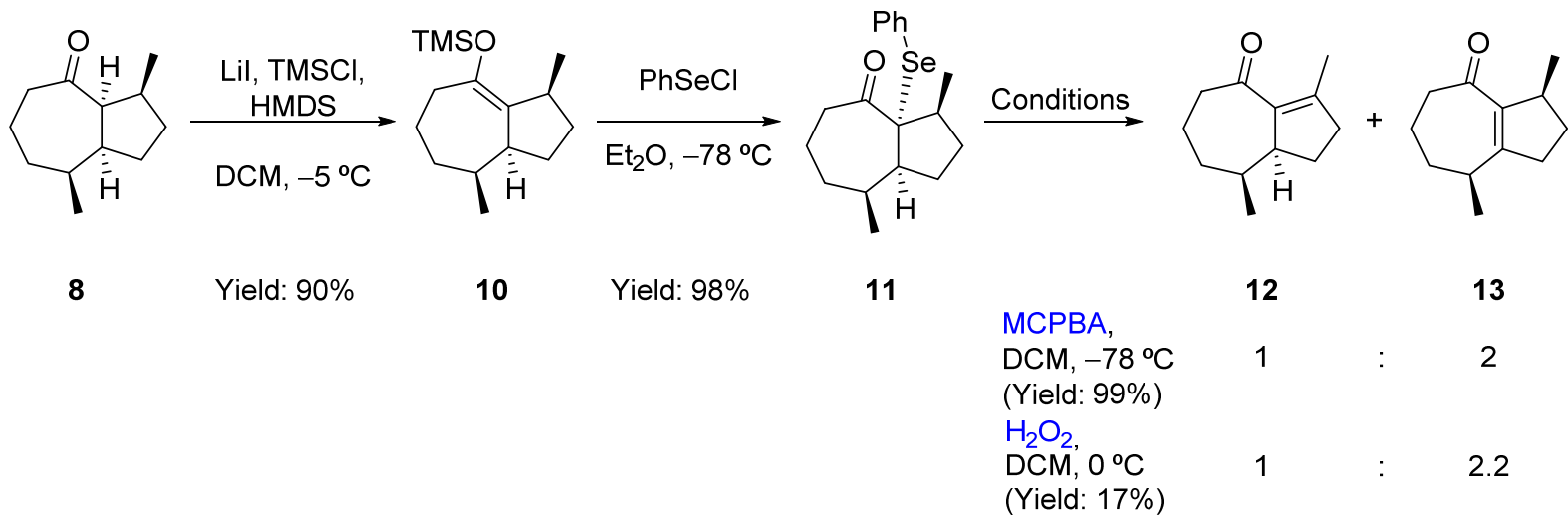

Scheme 7. Synthesis of compound $\mathbf{1 1}$ and elimination reaction to form enone $\mathbf{1 2 .}$

An alternative approach for the construction of the $\alpha, \beta$-unsaturated system was also tested by subjecting silyl enol ether 10 to Ito-Saegusa conditions [56-59]. However, when adduct 8 was exposed to $\mathrm{Pd}(\mathrm{OAc})_{2}$ in $\mathrm{CH}_{3} \mathrm{CN}$ at $65^{\circ} \mathrm{C}$, a 2:1 mixture of regioisomers was obtained, being 12 and undesired enone $\mathbf{1 3}$ formed as main product (Scheme 8).

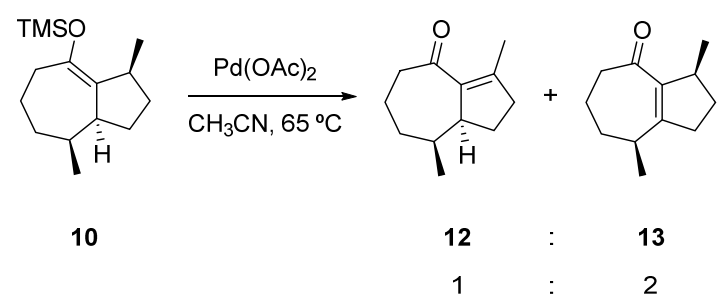

Scheme 8. Ito-Saegusa approach for the synthesis of enone $\mathbf{1 2 .}$

Other elimination procedures were also surveyed. In this sense, $\alpha$-bromoketone intermediate 14 was synthesized by treatment of adduct 8 with $\mathrm{N}$-bromosuccinimide in $\mathrm{Et}_{2} \mathrm{O}$ at room temperature in presence of $10 \mathrm{~mol} \%$ of $\mathrm{NH}_{4} \mathrm{OAc}$ [60], and subsequently exposed to different bases (Scheme 9). While DBU, NaH and LiHMDS did not promote the elimination process, even at high temperatures; pyridine, as well as previously applied conditions involving $\mathrm{Li}_{2} \mathrm{CO}_{3} / \mathrm{LiBr}$ rendered products $\mathbf{1 2}$ and $\mathbf{1 3}$ in a 1:4 and 1:20 ratio, respectively.

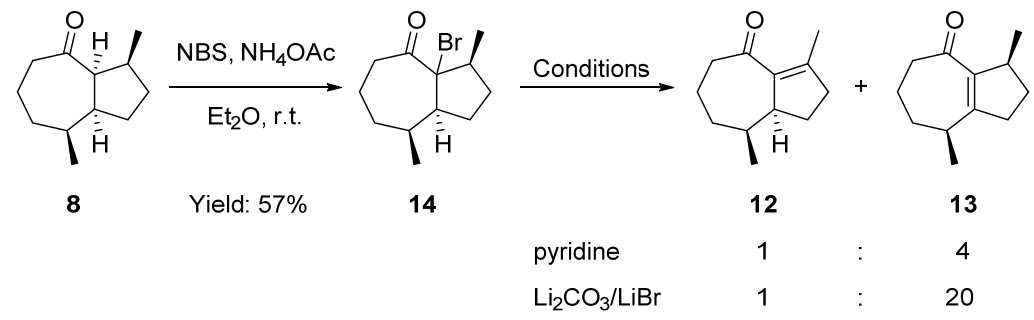

Scheme 9. Elimination through bromoketone 14. 
Although the different elimination protocols did not afford compound $\mathbf{1 2}$ as the major adduct, this methodology represents a formal total synthesis of (-)-Clavukerin A (Scheme 10) [43].<smiles>CC1=C2CCC(C)C2C(C)CCC1=O</smiles>

12

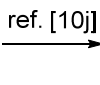

(-)-Clavukerin A

Scheme 10. Formal total synthesis of (-)-Clavukerin A.

2.4. Attempt to the Synthesis Guaia-5(6)-en-11-ol; Synthesis of (-)- $\gamma$-Gurjunene and Non-Natural 1-epi-11,12-didehydro-4,5-dihydroisoguaiane

In view of the obtained results, we decided now to focus our efforts on the synthesis of Guaia-5(6)-en-11-ol, a sesquiterpenoid from the guaiane family with a very related structure and that was expected to be readily accessible from adduct 8 (Scheme 11).

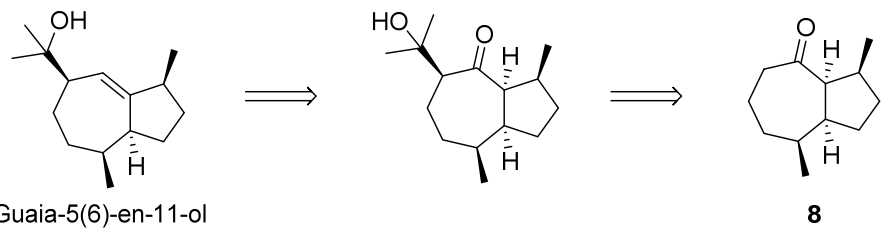

Scheme 11. Retrosynthetic analysis for the synthesis of Guaia-5(6)-en-11-ol starting from 8.

Taking this fact into account we initially introduced the lateral three atom carbon chain through aldol reaction. For this purpose, a kinetic deprotonation was performed with LDA at $-78{ }^{\circ} \mathrm{C}$ followed by zinc chloride-promoted aldol reaction [61,62], affording adduct 15 as a single diastereomer in 60\% yield, although with the wrong configuration at the newly generated stereogenic center (Scheme 12). The relative stereochemistry of the new stereocenter was determined by NMR analysis, through the observation of nuclear Overhauser effect (n.O.e.) between the hydrogen atom at C-7 and the methyl groups at C-4 and $\mathrm{C}-10$. Therefore, it was concluded that aldol 15 could not be employed as precursor in the total synthesis of Guaia-5(6)-en-11-ol, although we could use it successfully for the total synthesis of $(-)-\gamma$-Gurjunene as reported earlier by us [11].
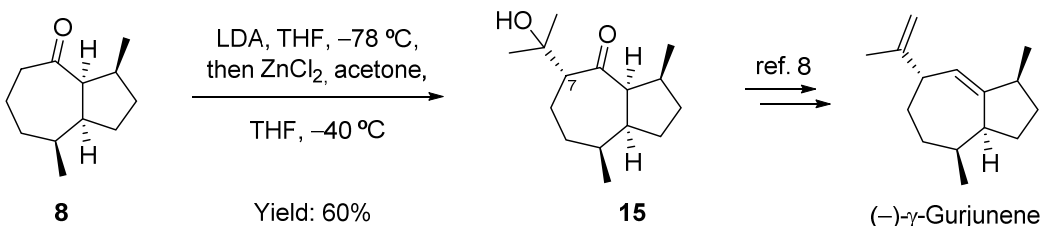

Scheme 12. Aldol reaction for the synthesis of $\mathbf{1 5}$ and application to the synthesis of $(-)-\gamma$-Gurjunene.

Nevertheless, we directed our attention to the possibility of synthesizing the natural isomer of this compound epi- $\gamma$-Gurjunene, which was conducted starting from compound 3 (Scheme 13). Thus, conjugate addition of Gilman cuprate was subsequently followed by in situ catalytic hydrogenation, delivering the corresponding adduct in $73 \%$ yield as a 3:1 mixture of epimers (16 and $\left.\mathbf{1 6}^{\prime}\right)$ at the $\alpha$-stereocentre to the ketone moiety, which is not relevant for the total synthesis as this stereocentre is not present on the final product. Next, aldol reaction was carried out under the same conditions as shown before, providing compound 16 (CCDC 2118405) as a single diastereoisomer and whose stereostructure could be confirmed by $\mathrm{X}$-ray analysis. Compound 17 was next submitted to elimination reaction with Burguess reagent in order to obtain the isopropenyl alkyl chain in 18. Finally, DIBAL$\mathrm{H}$ promoted carbonyl reduction produced a mixture of isomers 19 and $19^{\prime}$ which were 
subjected to a second elimination reaction using Martin sulfurane. However, all attempts to obtain epi- $\gamma$-Gurjunene were not successful leading in all cases to the isolation of 1-epi11,12-didehydro-4,5-dihydroisoguaiene, which is the non-natural isomer of isoguaiene.

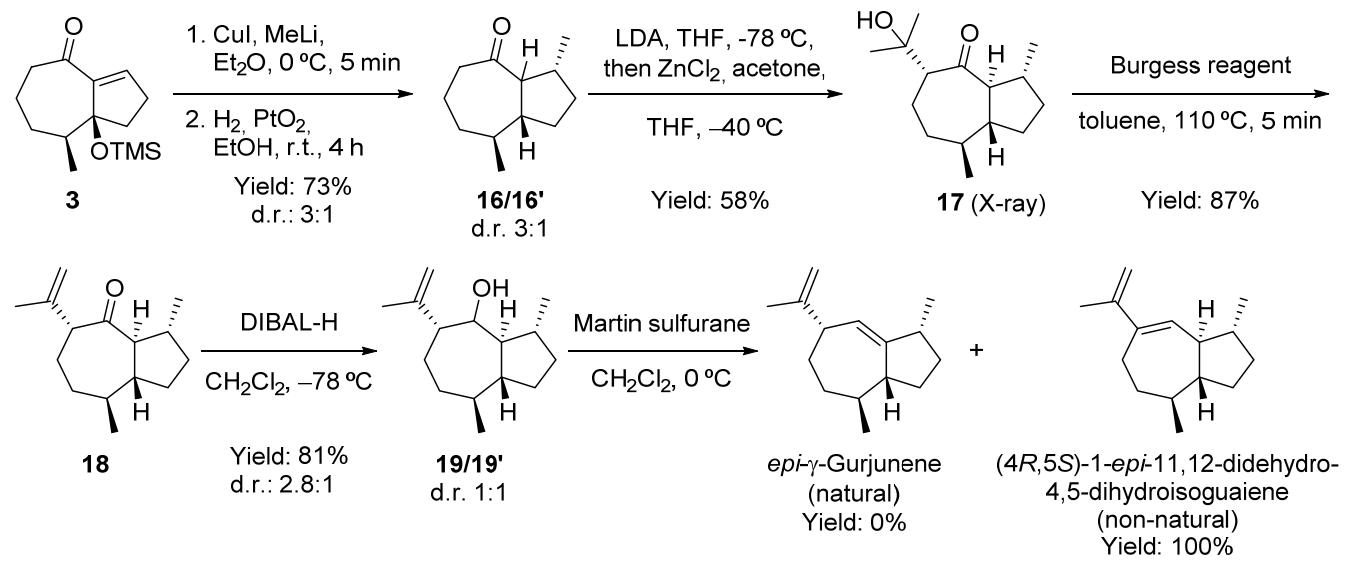

Scheme 13. Attempts to the synthesis of natural epi- $\gamma$-Gurjunene that led to the synthesis of epididehydrodihydroisoguaiene.

\section{Materials and Methods}

Nuclear magnetic resonance proton and carbon spectra $\left({ }^{1} \mathrm{H} \mathrm{NMR},{ }^{13} \mathrm{C} \mathrm{NMR}\right)$ were acquired at $25{ }^{\circ} \mathrm{C}$ on a Bruker AC-300 spectrometer (Bruker BioSpin GmbH, Silberstreifen 4, 76287 Rheinstetten, Billerica, MA, USA), infrared spectra (IR) in a Jasco FT/IR 4100 (ATR) (Jasco, Hachioji, Tokyo 193-0835, Japan) and high-resolution mass spectra (HRMS) on an Acquity UPLC coupled to a QTOF mass spectrometer (SYNAPT G2) using electrospray ionization $\left(\mathrm{ESI}^{+}\right.$) (Waters, Milford, MA, United States). X-ray data collections were performed in an Agilent Supernova diffractometer (Agilent, Santa Clara, CA, United States). Solvents and reagents were used without further purification. Anhydrous solvents were dried with activated molecular sieves [63,64]. Thermo Haake EK90 refrigerators (Thermo Fisher Scientific Inc., Waltham, MA, USA) were used for performing reactions at reduced temperatures. For flash chromatography Silicycle 40-63, 230-400 mesh silica gel was used (SiliCycle Inc., Quebec, QC, Canada) [65]. Removal of the solvents were performed under reduced pressure Büchi R-2 series rotatory evaporators (Buchi, Flawil, Switzerland). Precision weighing was made in a Sartorius Analytical Balance $( \pm 0.1 \mathrm{mg})$ (Sartorius, Goettingen, Germany). Note: Except those reactions performed during the synthesis of $(-)-\gamma$-Gurjunene (Scheme 12) for which enantiomerically pure (8S,8aS)-2 was used, the syntheses described herein were accomplished in a racemic manner. The authors reserve the right to carry out the reactions described herein enantioselectively. For further details see "Supplementary Materials":

$N^{\prime}-\left(\left(3 S^{*}, 3 \mathrm{a} R^{*}, 4 E, 8 S^{*}, 8 \mathrm{a} S^{*}\right)-3,8\right.$-dimethyloctahydroazulen-4(1H)-ylidene)-4-methylbenzenesulfonohydrazide (9). To a solution of compound $8(15.5 \mathrm{mg}, 0.086 \mathrm{mmol})$ in EtOH $(1.3 \mathrm{~mL})$ at $\mathrm{rt}$, tosylhydrazine $(20 \mathrm{mg}, 0.107 \mathrm{mmol})$ and acetic acid $(8 \mu \mathrm{L}, 0.140 \mathrm{mmol})$ were subsequently added. The mixture was stirred at rt during 8 days. The crude product was evaporated and purified by flash column chromatography (petroleum ether/EtOAc 8:1) affording the desired compound $9(2.99 \mathrm{mg}, 0.0086 \mathrm{mmol})$ as a white solid that easily decompose in solution. Yield: $10 \% .{ }^{1} \mathrm{H}$ NMR $\left(300 \mathrm{MHz}, \mathrm{CDCl}_{3}\right) \delta 7.88-7.81(\mathrm{~m}, 2 \mathrm{H}), 7.31-7.27$ (m, 2H), 7.17-7.07 (bs, 1H), $2.42(\mathrm{~s}, 3 \mathrm{H}), 2.38-2.23(\mathrm{~m}, 2 \mathrm{H}), 2.15-2.02(\mathrm{~m}, 2 \mathrm{H}), 2.01-1.85(\mathrm{~m}$, 2H), 1.75-1.65 (m, 4H), 1.64-1.48 (m, 2H), 1.45-1.32 (m, 2H), $0.89(\mathrm{~d}, J=6.9 \mathrm{~Hz}, 3 \mathrm{H}), 0.79$ $(\mathrm{d}, J=6.3 \mathrm{~Hz}, 3 \mathrm{H})$. HRMS: Calculated for $\left[\mathrm{C}_{19} \mathrm{H}_{29} \mathrm{~N}_{2} \mathrm{O}_{2} \mathrm{~S}\right]^{+}: 349.1944\left[(\mathrm{M}+\mathrm{H})^{+}\right]$; found: 349.1950. M.p. (petroleum ether/EtOAc): melted.

$\left(\left(\left(3 S^{*}, 8 S^{*}, 8 \mathrm{a} S^{*}\right)\right.\right.$-3,8-dimethyl-1,2,3,5,6,7,8,8a-octahydroazulen-4-yl)oxy)trimethylsilane (10). To a solution of compound $8(9.0 \mathrm{mg}, 0.050 \mathrm{mmol})$ in dry $\mathrm{CH}_{2} \mathrm{Cl}_{2}(0.3 \mathrm{~mL})$ at $-5{ }^{\circ} \mathrm{C}$ (ice $/ \mathrm{NaCl}$ bath) HMDS $(13.5 \mu \mathrm{L}, 0.0645 \mathrm{mmol})$ was added. The mixture was stirred for 
$1 \mathrm{~min}$ and then previously dried LiI $(7.6 \mathrm{mg}, 0.0565 \mathrm{mmol})$ and TMSCl $(6.3 \mu \mathrm{L}, 0.05 \mathrm{mmol})$ were subsequently added. The mixture was stirred at $-5^{\circ} \mathrm{C}$ for $160 \mathrm{~min}$ observing the appearance of a white suspension. The crude product was then poured into ice and $\mathrm{CH}_{2} \mathrm{Cl}_{2}$ $(5 \mathrm{~mL})$ and a saturated solution of $\mathrm{NaHCO}_{3}(5 \mathrm{~mL})$ was added. The phases were separated and the organic layer washed with a saturated solution of $\mathrm{NaHCO}_{3}(5 \mathrm{~mL})$. The organic phase was dried over anhydrous $\mathrm{Na}_{2} \mathrm{SO}_{4}$, filtered and the solvent eliminated under reduced pressure affording the desired compound $10(11.3 \mathrm{mg}, 0.045 \mathrm{mmol})$ as a colorless oil that easily decomposes in solution. Yield: $90 \% .{ }^{1} \mathrm{H}$ NMR $\left(300 \mathrm{MHz}, \mathrm{CDCl}_{3}\right) \delta 2.73(\mathrm{dt}, J=23.9$, $8.2 \mathrm{~Hz}, 2 \mathrm{H}), 2.41-2.27(\mathrm{~m}, 1 \mathrm{H}), 2.07(\mathrm{dd}, J=15.7,6.6 \mathrm{~Hz}, 1 \mathrm{H}), 1.90-1.78(\mathrm{~m}, 1 \mathrm{H}), 1.78-1.23$ $(\mathrm{m}, 8 \mathrm{H}), 0.95(\mathrm{~d}, J=7.3 \mathrm{~Hz}, 3 \mathrm{H}), 0.86(\mathrm{~d}, J=7.0 \mathrm{~Hz}, 3 \mathrm{H}), 0.18(\mathrm{~s}, 9 \mathrm{H})$. HRMS: Calculated for $\left[\mathrm{C}_{18} \mathrm{H}_{29} \mathrm{OSi}\right]^{+}: 253.1982\left[(\mathrm{M}+\mathrm{H})^{+}\right]$; found: 253.1986 .

$\left(3 S^{*}, 3 \mathrm{a} R^{*}, 8 S^{*}, 8 \mathrm{a} S^{*}\right)-3,8$-dimethyl-3a-(phenylselanyl)octahydroazulen-4(1H)-one (11). To a solution of the compound $10(11.3 \mathrm{mg}, 0.045 \mathrm{mmol})$ in dry $\mathrm{Et}_{2} \mathrm{O}(0.14 \mathrm{~mL})$ at $-78{ }^{\circ} \mathrm{C}$ a

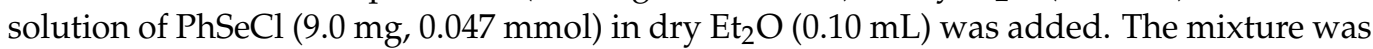
stirred at $-78{ }^{\circ} \mathrm{C}$ for $2 \mathrm{~h}$. Then, a saturated solution of $\mathrm{NaHCO}_{3}(5 \mathrm{~mL})$ and $\mathrm{Et}_{2} \mathrm{O}(5 \mathrm{~mL})$ were added. The phases were separated, washed with a saturated solution of $\mathrm{NaHCO}_{3}$ $(5 \mathrm{~mL})$, dried over anhydrous $\mathrm{Na}_{2} \mathrm{SO}_{4}$, filtered and the solvent eliminated under reduced pressure affording the desired compound $11(15.1 \mathrm{mg}, 0.044 \mathrm{mmol})$ as a colorless oil. Yield: 98\%. ${ }^{1} \mathrm{H}$ NMR (300 MHz, $\left.\mathrm{CDCl}_{3}\right)$ 8 7.65-7.52 (m, 2H), 7.43-7.23 (m, 3H), 2.54 (ddd, J = 11.4, 7.2, $1.9 \mathrm{~Hz}, 1 \mathrm{H}), 2.41-2.28(\mathrm{~m}, 1 \mathrm{H}), 2.25-2.15(\mathrm{~m}, 1 \mathrm{H}), 2.13-1.98(\mathrm{~m}, 1 \mathrm{H}), 1.98-1.72(\mathrm{~m}, 4 \mathrm{H})$, $1.67-1.35(\mathrm{~m}, 5 \mathrm{H}), 1.09(\mathrm{~d}, J=6.9 \mathrm{~Hz}, 3 \mathrm{H}), 0.88(\mathrm{~d}, J=7.0 \mathrm{~Hz}, 3 \mathrm{H}) .{ }^{13} \mathrm{C} \mathrm{NMR}(75 \mathrm{MHz}$, $\left.\mathrm{CDCl}_{3}\right) \delta 212.8,139.3,131.7,129.2,128.9,48.96,48.87,45.0,44.9,32.1,31.4,30.3,26.1,23.6$, 21.3, 14.9. HRMS: Calculated for $\left[\mathrm{C}_{18} \mathrm{H}_{25} \mathrm{OSe}^{+}\right.$: $337.1065\left[(\mathrm{M}+\mathrm{H})^{+}\right]$; found: 337.1066.

$\left(3 S^{*}, 8 S^{*}\right)$-3,8-dimethyl-2,3,5,6,7,8-hexahydroazulen-4(1H)-one (13). To a solution of compound $11(15.1 \mathrm{mg}, 0.044 \mathrm{mmol})$ in in dry $\mathrm{CH}_{2} \mathrm{Cl}_{2}(0.7 \mathrm{~mL})$ cooled at $-78{ }^{\circ} \mathrm{C}$ was added MCPBA $(15.5 \mathrm{mg}, 0.09 \mathrm{mmol})$. The mixture was stirred for $60 \mathrm{~min}$ at this temperature and then a saturated solution of $\mathrm{NaHCO}_{3}(5 \mathrm{~mL})$ and $\mathrm{CH}_{2} \mathrm{Cl}_{2}(5 \mathrm{~mL})$ were added. The phases were separated, washed with a saturated solution of $\mathrm{NaHCO}_{3}(5 \mathrm{~mL})$, dried over anhydrous $\mathrm{Na}_{2} \mathrm{SO}_{4}$, filtered and the solvent eliminated under reduced pressure affording the desired compound as a separable 1:2 mixture of 12:13 $(8.0 \mathrm{mg}, 0.044 \mathrm{mmol})$. The crude product was purified by flash column chromatography (petroleum ether/EtOAc 20:1) affording the major compound $13(5.30 \mathrm{mg}, 0.029 \mathrm{mmol})$ as a colorless oil. Yield: $66 \% .{ }^{1} \mathrm{H}$ NMR $\left(300 \mathrm{MHz}, \mathrm{CDCl}_{3}\right) \delta 3.16-3.02(\mathrm{~m}, 1 \mathrm{H}), 2.76(\mathrm{dtt}, J=18.1,8.2,1.6 \mathrm{~Hz}, 1 \mathrm{H}), 2.68-2.59$ $(\mathrm{m}, 1 \mathrm{H}), 2.54(\mathrm{dd}, J=7.3,5.0 \mathrm{~Hz}, 2 \mathrm{H}), 2.34(\mathrm{dddt}, J=17.9,9.1,3.8,1.1 \mathrm{~Hz}, 1 \mathrm{H}), 2.03-1.70$ $(\mathrm{m}, 4 \mathrm{H}), 1.64-1.48(\mathrm{~m}, 1 \mathrm{H}), 1.40(\mathrm{ddt}, J=12.2,8.4,3.6 \mathrm{~Hz}, 1 \mathrm{H}), 1.15(\mathrm{~d}, J=7.1 \mathrm{~Hz}, 3 \mathrm{H})$, $1.05(\mathrm{~d}, J=6.8 \mathrm{~Hz}, 3 \mathrm{H}) .{ }^{13} \mathrm{C} \mathrm{NMR}\left(75 \mathrm{MHz}, \mathrm{CDCl}_{3}\right) \delta 202.5,160.8,142.7,44.3,41.5,36.8$, $36.1,34.2,30.5,20.1,19.8,19.8$. HRMS: Calculated for $\left[\mathrm{C}_{12} \mathrm{H}_{18} \mathrm{O}\right]^{+}: 178.1358\left[(\mathrm{M}+\mathrm{H})^{+}\right]$; found: 178.1365 .

$\left(3 S^{*}, 8 S^{*}, 8\right.$ a $\left.S^{*}\right)$-3a-bromo-3,8-dimethyloctahydroazulen-4(1H)-one (14). To a solution of compound $8(18 \mathrm{mg}, 0.10 \mathrm{mmol})$ in $\operatorname{dry~}^{2} \mathrm{E}_{2} \mathrm{O}(0.3 \mathrm{~mL})$ at rt, NBS $(18.7 \mathrm{mg}, 0.105 \mathrm{mmol})$ and $\mathrm{NH}_{4} \mathrm{OAc}(0.8 \mathrm{mg}, 0.01 \mathrm{mmol})$ were added. The mixture was stirred at $\mathrm{rt}$ for $4 \mathrm{~h}$. After this time, solids were filtered off and volatiles eliminated under reduced pressure. The crude product was purified by flash column chromatography (petroleum ether/EtOAc gradient from 100:0 to 100:1) affording compound $14(14.7 \mathrm{mg}, 0.057$. mmol) as a colorless oil. Yield: 57\%. ${ }^{1} \mathrm{H}$ NMR $\left(300 \mathrm{MHz}, \mathrm{CDCl}_{3}\right) \delta 2.95$ (dddd, $\left.J=12.7,5.8,4.8,0.9 \mathrm{~Hz}, 1 \mathrm{H}\right), 2.60$ $(\mathrm{td}, J=10.1,3.3 \mathrm{~Hz}, 1 \mathrm{H}), 2.55-2.45(\mathrm{~m}, 1 \mathrm{H}), 2.30(\mathrm{ddd}, J=12.7,10.6,5.2 \mathrm{~Hz}, 1 \mathrm{H}), 2.27-2.11$ $(\mathrm{m}, 1 \mathrm{H}), 2.01-1.74(\mathrm{~m}, 3 \mathrm{H}), 1.73-1.48(\mathrm{~m}, 4 \mathrm{H}), 1.46-1.33(\mathrm{~m}, 1 \mathrm{H}), 1.08(\mathrm{~d}, J=6.9 \mathrm{~Hz}, 3 \mathrm{H})$, $0.99(\mathrm{~d}, J=7.0 \mathrm{~Hz}, 3 \mathrm{H}) .{ }^{13} \mathrm{C}$ NMR $\left(75 \mathrm{MHz}, \mathrm{CDCl}_{3}\right) \delta 206.2,81.5,57.2,50.2,42.9,32.95$, $29.9,29.4,23.9,23.2,21.4,14.0$. HRMS: Calculated for $\left[\mathrm{C}_{12} \mathrm{H}_{20} \mathrm{BrO}\right]^{+}: 259.0962\left[(\mathrm{M}+\mathrm{H})^{+}\right]$; found: 259.0960 .

$(3 R, 8 S, 8 \mathrm{a} R)$-3,8-dimethyloctahydroazulen-4(1H)-one (16 and $\left.\mathbf{1 6}^{\prime}\right)$. To a solution of compound $3(65 \mathrm{mg}, 0.257 \mathrm{mmol})$ in dry $\mathrm{Et}_{2} \mathrm{O}(1.0 \mathrm{~mL})$ at $0{ }^{\circ} \mathrm{C}$ was added freshly prepared solution of $\mathrm{Me}_{2} \mathrm{CuLi}$ in $\mathrm{Et}_{2} \mathrm{O}(0.4 \mathrm{~mL}, 0.24 \mathrm{mmol}, 0.6 \mathrm{M})$. The mixture was filtered through a short pad of Celite and then the solvent removed under reduced pressure. The crude 
product was dissolved in $\mathrm{EtOH}(2 \mathrm{~mL})$ and $\mathrm{PtO}_{2}(15 \mathrm{mg}, 0.066 \mathrm{mmol})$ was added. The mixture was exposed to an hydrogen atmosphere ( $1 \mathrm{~atm}$ with a balloon) for $5 \mathrm{~h}$. The crude was evaporated and the desired compound was obtained as a separable 1:3 mixture of isomers 16 and $16^{\prime}$, respectively ( $33 \mathrm{mg}, 0.185 \mathrm{mmol}$ ). Combined yield: $73 \%$. Purification by flash column chromatography afforded compound 16 and $\mathbf{1 6}^{\prime}$ as a colorless oils. Data for isomer 16: ${ }^{1} \mathrm{H}$ NMR $\left(300 \mathrm{MHz}, \mathrm{C}_{6} \mathrm{D}_{6}\right) \delta 2.93-2.68(\mathrm{~m}, 1 \mathrm{H}), 2.33-2.21(\mathrm{~m}, 3 \mathrm{H}), 1.92-1.69$ $(\mathrm{m}, 2 \mathrm{H}), 1.68-1.34(\mathrm{~m}, 4 \mathrm{H}), 1.32-1.13(\mathrm{~m}, 4 \mathrm{H}), 1.04(\mathrm{~d}, J=6.7 \mathrm{~Hz}, 3 \mathrm{H}), 0.82(\mathrm{~d}, J=6.0 \mathrm{~Hz}$, $3 \mathrm{H}) .{ }^{13} \mathrm{C}$ NMR $\left(75 \mathrm{MHz}, \mathrm{C}_{6} \mathrm{D}_{6}\right) \delta 210.9,63.6,52.1,44.1,42.6,37.8,35.2,32.1,31.9,22.5,22.0$, 20.3. HRMS: Calculated for $\left[\mathrm{C}_{12} \mathrm{H}_{21} \mathrm{O}\right]^{+}: 180.1587\left[(\mathrm{M}+\mathrm{H})^{+}\right]$; found: 180.1577. Data for isomer 16': ${ }^{1} \mathrm{H}$ NMR (300 MHz, $\left.\mathrm{C}_{6} \mathrm{D}_{6}\right) \delta 2.47-2.06(\mathrm{~m}, 5 \mathrm{H}), 1.81(\mathrm{dt}, J=12.5,6.5 \mathrm{~Hz}, 1 \mathrm{H})$, $1.60(\mathrm{dt}, J=20.0,8.4 \mathrm{~Hz}, 3 \mathrm{H}), 1.50-1.18(\mathrm{~m}, 6 \mathrm{H}), 1.12(\mathrm{~d}, J=6.4 \mathrm{~Hz}, 3 \mathrm{H}), 0.82(\mathrm{~d}, J=7.1 \mathrm{~Hz}$, 3H). ${ }^{13} \mathrm{C}$ NMR $\left(75 \mathrm{MHz}, \mathrm{C}_{6} \mathrm{D}_{6}\right) \delta 211.8,64.2,44.9,42.5,38.1,35.9,35.4,34.0,28.3,23.8,20.1$, 18.6. HRMS: Calculated for $\left[\mathrm{C}_{12} \mathrm{H}_{21} \mathrm{O}\right]^{+}: 180.1587\left[(\mathrm{M}+\mathrm{H})^{+}\right]$; found: 180.1579 .

$\left(3 R^{*}, 3 \mathrm{a} S^{*}, 5 R^{*}, 8 S^{*}, 8 \mathrm{a} R^{*}\right)$-5-(2-hydroxypropan-2-yl)-3,8-dimethyloctahydroazulen-4 $(1 \mathrm{H})$ one (17). To a freshly prepared solution of LDA in THF $(0.45 \mathrm{~mL})$ prepared using $i \operatorname{Pr}_{2} \mathrm{NH}$ $(56 \mu \mathrm{L}, 0.399 \mathrm{mmol})$ and $n$-BuLi $(0.195 \mathrm{~mL}, 0.33 \mathrm{mmol}, 1.7 \mathrm{M})$ was added a solution of compound $16(24.0 \mathrm{mg}, 0.133 \mathrm{mmol})$ in $\mathrm{THF}(0.3 \mathrm{~mL})$ at $-78^{\circ} \mathrm{C}$. The reaction was stirred at this temperature for $1 \mathrm{~h}$ and then warmed to $-40{ }^{\circ} \mathrm{C}$. Then $\mathrm{ZnCl}_{2}(0.23 \mathrm{~mL}, 0.16 \mathrm{mmol}$, $0.7 \mathrm{M})$ and dry acetone $(0.110 \mathrm{~mL}, 1.46 \mathrm{mmol})$ were subsequently added. The reaction was stirred at $-40{ }^{\circ} \mathrm{C}$ for further $1 \mathrm{~h}$ and then the mixture was treated with a saturated aqueous solution of $\mathrm{NH}_{4} \mathrm{Cl}(5 \mathrm{~mL})$ and $\mathrm{Et}_{2} \mathrm{O}(5 \mathrm{~mL})$ was added. The phases were separated, back extracted with $\mathrm{Et}_{2} \mathrm{O}(2 \times 5 \mathrm{~mL})$ and the organic layers dried over anhydrous $\mathrm{Na}_{2} \mathrm{SO}_{4}$. Filtration and elimination of solvent afforded the crude product which was purified by flash column chromatography (petroleum ether/EtOAc gradient from 49:1 to 9:1) affording major compound $17(18.3 \mathrm{mg}, 0.077 \mathrm{mmol})$ as a white solid. Yield: $58 \%$. ${ }^{1} \mathrm{H} \mathrm{NMR}(300 \mathrm{MHz}$, $\left.\mathrm{C}_{6} \mathrm{D}_{6}\right) \delta 2.95(\mathrm{~s}, 1 \mathrm{H}), 2.86-2.70(\mathrm{~m}, 1 \mathrm{H}), 2.46(\mathrm{dd}, J=9.9,9.9 \mathrm{~Hz}, 1 \mathrm{H}), 2.30(\mathrm{dd}, J=12.3$, $4.4 \mathrm{~Hz}, 1 \mathrm{H}), 1.92-1.60(\mathrm{~m}, 4 \mathrm{H}), 1.59-1.43(\mathrm{~m}, 1 \mathrm{H}), 1.27^{*}(\mathrm{~s}, 3 \mathrm{H}), 1.27-1.14(\mathrm{~m}, 4 \mathrm{H}), 1.14^{*}$ (s, $3 \mathrm{H}), 1.05(\mathrm{~d}, J=6.6 \mathrm{~Hz}, 3 \mathrm{H}), 0.82(\mathrm{~d}, J=6.3 \mathrm{~Hz}, 3 \mathrm{H}) .{ }^{13} \mathrm{C} \mathrm{NMR}\left(75 \mathrm{MHz}, \mathrm{C}_{6} \mathrm{D}_{6}\right) \delta 13 \mathrm{C} \mathrm{NMR}$ (75 MHz, C6D6) $\delta$ 216.4, 72.4, 63.9, 63.8, 53.4, 42.5, 36.7, 36.3, 32.0, 31.8, 29.2, 27.4, 24.7, 21.7, 19.9. HRMS: Calculated for $\left[\mathrm{C}_{15} \mathrm{H}_{27} \mathrm{O}_{2}\right]^{+}: 239.2006\left[(\mathrm{M}+\mathrm{H})^{+}\right]$; found: 239.2000 .

$\left(3 R^{*}, 3 \mathrm{a} S^{*}, 5 R^{*}, 8 S^{*}, 8 \mathrm{a} R^{*}\right)$-3,8-dimethyl-5-(prop-1-en-2-yl)octahydroazulen-4(1H)-one (18). A solution of compound $17(116 \mathrm{mg}, 0.486 \mathrm{mmol})$ and Burguess reagent $(460 \mathrm{mg}, 1.94 \mathrm{mmol})$ in toluene $(25 \mathrm{~mL})$ was heated under reflux. After $5 \mathrm{~min}$ the mixture was concentrated and the crude product was purified by flash column chromatography (petroleum ether/EtOAc gradient 19:1) affording compound $18(93 \mathrm{mg}, 0.42 \mathrm{mmol})$ as a colorless oil. Yield: $87 \%$. ${ }^{1} \mathrm{H}$ NMR (300 MHz, C $\left.6 \mathrm{D}_{6}\right) \delta 4.95(\mathrm{~s}, 1 \mathrm{H}), 4.91(\mathrm{~s}, 1 \mathrm{H}), 3.04-2.90(\mathrm{~m}, 1 \mathrm{H}), 2.77$ (tt, $J=13.4$, $4.5 \mathrm{~Hz}, 1 \mathrm{H}), 2.43(\mathrm{dd}, J=10.2,10.2 \mathrm{~Hz}, 1 \mathrm{H}), 1.97-1.81^{*}(\mathrm{~m}, 2 \mathrm{H}), 1.82^{*}(\mathrm{~s}, 3 \mathrm{H}), 1.79-1.56(\mathrm{~m}$, $3 \mathrm{H}), 1.43-1.08(\mathrm{~m}, 5 \mathrm{H}), 0.96(\mathrm{~d}, J=6.6 \mathrm{~Hz}, 3 \mathrm{H}), 0.83(\mathrm{~d}, J=6.4 \mathrm{~Hz}, 3 \mathrm{H}) .{ }^{13} \mathrm{C}$ NMR $(75 \mathrm{MHz}$, $\left.\mathrm{C}_{6} \mathrm{D}_{6}\right) \delta 210.3,144.0,111.5,61.6,61.3,54.2,42.9,36.0,36.0,32.0,32.0,28.1,22.7,21.8,19.4$. HRMS: Calculated for $\left[\mathrm{C}_{15} \mathrm{H}_{25} \mathrm{O}\right]^{+}: 221.1900\left[(\mathrm{M}+\mathrm{H})^{+}\right]$; found: 221.1901.

$\left(3 R^{*}, 3 \mathrm{a} S^{*}, 5 R^{*}, 8 S^{*}, 8 \mathrm{a} R^{*}\right)-3,8$-dimethyl-5-(prop-1-en-2-yl)decahydroazulen-4-ol (19 and $\left.19^{\prime}\right)$. To a solution of compound $18(74 \mathrm{mg}, 0.33 \mathrm{mmol})$ in $\mathrm{CH}_{2} \mathrm{Cl}_{2}(6 \mathrm{~mL})$ at $-78{ }^{\circ} \mathrm{C}$, a solution of DIBAL-H $(1.00 \mathrm{~mL}, 1.00 \mathrm{mmol}, 1 \mathrm{M})$ was added. The mixture was stirred for $5 \mathrm{~min}$ at this temperature and then quenched with a $\mathrm{H}_{2} \mathrm{O}(5 \mathrm{~mL})$ and diluted with $\mathrm{CH}_{2} \mathrm{Cl}_{2}(5 \mathrm{~mL})$. The phases were separated, the organic dried over anhydrous $\mathrm{Na}_{2} \mathrm{SO}_{4}$, and filtration and elimination of solvent afforded the crude product which was purified by flash column chromatography (petroleum ether/EtOAc 19:1) affording major compound 19 (43.3 mg, $0.19 \mathrm{mmol})$ and $\mathbf{1 9}^{\prime}(18 \mathrm{mg}, 0.080)$ as a colorless oil. Combined yield: $81 \%$. Data for isomer 19: ${ }^{1} \mathrm{H} \mathrm{NMR}\left(300 \mathrm{MHz}, \mathrm{CDCl}_{3}\right.$ ) ( ${ }^{*}$ indicates partially overlapped resonances) $\delta$ $5.01(\mathrm{~s}, 1 \mathrm{H}), 4.74(\mathrm{~s}, 1 \mathrm{H}), 3.59(\mathrm{dd}, J=8.3,4.2 \mathrm{~Hz}, 1 \mathrm{H}), 2.24(\mathrm{dd}, J=9.8,4.2 \mathrm{~Hz}, 1 \mathrm{H}), 2.10-1.93$ (m, 1H), 1.93-1.70 (m, 7H), 1.69-1.55 (m, 1H), 1.54-1.18 (m, 6H), 1.10-0.94* (m, 1H), 1.06* $(\mathrm{d}, J=7.0 \mathrm{~Hz}, 3 \mathrm{H}), 0.89(\mathrm{~d}, J=5.8 \mathrm{~Hz}, 3 \mathrm{H}) .{ }^{13} \mathrm{C} \mathrm{NMR}\left(75 \mathrm{MHz}, \mathrm{CDCl}_{3}\right) \delta 149.2,112.7,74.6$, $58.4,52.4,48.6,42.1,41.9,40.8,33.1,31.7,25.8,23.5,23.1,21.9$. Calculated for $\left[\mathrm{C}_{15} \mathrm{H}_{27} \mathrm{O}\right]^{+}$: 223.2056 [(M+H) ${ }^{+}$; found: 223.2065. Data for isomer $19^{\prime}:{ }^{1} \mathrm{H} \mathrm{NMR}\left(300 \mathrm{MHz}, \mathrm{CDCl}_{3}\right) \delta$ 
$4.77(\mathrm{~s}, 1 \mathrm{H}), 4.72(\mathrm{~s}, 1 \mathrm{H}), 3.79(\mathrm{dt}, J=7.1,3.5 \mathrm{~Hz}, 1 \mathrm{H}), 2.16-1.99(\mathrm{~m}, 2 \mathrm{H}), 1.92-1.61(\mathrm{~m}, 7 \mathrm{H})$, $1.61-1.50(\mathrm{~m}, 2 \mathrm{H}), 1.49-1.33(\mathrm{~m}, 3 \mathrm{H}), 1.32-1.08(\mathrm{~m}, 3 \mathrm{H}), 0.98(\mathrm{~d}, J=6.7 \mathrm{~Hz}, 3 \mathrm{H}), 0.91(\mathrm{~d}$, $J=6.2 \mathrm{~Hz}, 3 \mathrm{H}) .{ }^{13} \mathrm{C} \mathrm{NMR}\left(75 \mathrm{MHz}, \mathrm{CDCl}_{3}\right) \delta 149.4,110.7,71.3,57.1,56.0,44.5,42.0,39.8$, 36.6, 33.6, 30.8, 28.7, 22.1, 20.3, 19.2. HRMS: Calculated for $\left[\mathrm{C}_{15} \mathrm{H}_{27} \mathrm{O}\right]^{+}: 223.2056\left[(\mathrm{M}+\mathrm{H})^{+}\right]$; found: 223.2049 .

$\left(4 R^{*}, 5 S^{*}\right)$-1-epi-11,12-didehydro-4,5-dihydroisoguaiene. To a solution of compound 19 (30 mg, $0.134 \mathrm{mmol})$ in $\mathrm{CH}_{2} \mathrm{Cl}_{2}(2 \mathrm{~mL})$ at $0{ }^{\circ} \mathrm{C}$ was added the Martin sulfurane $(270 \mathrm{mg}$, $0.40 \mathrm{mmol})$ dissolved in $\mathrm{CH}_{2} \mathrm{Cl}_{2}(1 \mathrm{~mL})$. The mixture was stirred for $2 \mathrm{~h}$ and then the crude product concentrated and purified by flash column chromatography (petroleum ether) affording the title compound $(27.3 \mathrm{mg}, 0.13 \mathrm{mmol})$ as a colorless oil. ${ }^{1} \mathrm{H} \mathrm{NMR}(300 \mathrm{MHz}$, $\left.\mathrm{CDCl}_{3}\right)$ (* indicates partially overlapped resonances) $\delta 5.78(\mathrm{~d}, J=4.3 \mathrm{~Hz}, 1 \mathrm{H}), 5.00(\mathrm{~d}$, $J=1.4 \mathrm{~Hz}, 1 \mathrm{H}), 4.85(\mathrm{~s}, 1 \mathrm{H}), 2.53(\mathrm{dd}, J=14.9,7.8 \mathrm{~Hz}, 1 \mathrm{H}), 2.28-2.18(\mathrm{~m}, 1 \mathrm{H}), 1.90^{*}(\mathrm{~s}, 3 \mathrm{H})$ $1.89-1.65^{*}(\mathrm{~m}, 4 \mathrm{H}), 1.51-1.41(\mathrm{~m}, 1 \mathrm{H}), 1.36-1.11(\mathrm{~m}, 6 \mathrm{H}), 1.01(\mathrm{~d}, J=6.3 \mathrm{~Hz}, 3 \mathrm{H}), 0.88(\mathrm{~d}$, $J=6.7 \mathrm{~Hz}, 6 \mathrm{H}) .{ }^{13} \mathrm{C} \mathrm{NMR}\left(75 \mathrm{MHz}, \mathrm{CDCl}_{3}\right) \delta 144.4,144.2,132.1,110.2,52.5,51.3,43.9,42.0$, 34.6, 32.2, 31.0, 27.7, 22.2, 21.4, 19.6. HRMS: Calculated for $\left[\mathrm{C}_{15} \mathrm{H}_{25}\right]^{+}: 205.1951\left[(\mathrm{M}+\mathrm{H})^{+}\right]$; found: 205.1953.

\section{Conclusions}

The transannular Morita-Baylis-Hillman reaction using racemic chiral medium-sized cyclic ketoenone $\mathbf{1}$ under kinetic resolution conditions is a good approach to enantiopure 10-methyl substituted functionalized decahydroazulene derivatives. This reaction has been optimized and applied to the generation of the central core of guaiane and aremadendrane families of sesquiterpenoids. The enantioenriched $\mathrm{MBH}$ adduct has been used as starting material for the preparation of several sesquiterpene-related compounds such as $\gamma$-Gurjunene, Clavukerin A, non-natural 1-epi-11,12-didehydro-4,5-dihydroisoguaiane and an advanced intermediate in the synthesis of Palustrol.

Supplementary Materials: The following are available online at https: / www.mdpi.com/article / 10.3390/catal12010067/s1, Figures S1-S11: NMR spectra of new compounds.

Author Contributions: Conceptualization, methodology and validation, R.M. (Raquel Mato), R.M. (Rubén Manzano), E.R., L.P. and U.U.; formal analysis and investigation, R.M. (Raquel Mato), R.M. (Rubén Manzano), E.R. and J.L.V.; writing-original draft preparation, R.M. (Raquel Mato), L.C. and J.L.V.; writing - review and editing, E.R.; supervision, project administration and funding acquisition, L.C. and J.L.V. All authors have read and agreed to the published version of the manuscript.

Funding: This research was funded by the Spanish Ministerio de Ciencia, Innovación y Universidades (MCIU), grant numbers FEDER-CTQ2017-83633P and FEDER-PID2020-118422-GB-I00 and by the Basque Government, grant number Grupos IT908-16.

Institutional Review Board Statement: Not applicable.

Informed Consent Statement: Not applicable.

Data Availability Statement: Not applicable.

Conflicts of Interest: The authors declare no conflict of interest. The funders had no role in the design of the study; in the collection, analyses, or interpretation of data; in the writing of the manuscript, or in the decision to publish the results.

\section{References}

1. Singh, G. Chemistry of Terpenoids and Carotenoids; Discovery Publishing Home: New Dehli, India, 2007.

2. Zhang, L.; Demain, A.L. Natural Products: Drug Discovery and Therapeutic Medicine; Human Press: Totowa, NJ, USA, 2005.

3. Thomson, R.H. The Chemistry of Natural Products; Blackie Academic \& Professional: Glasgow, Scotland, 1993.

4. Pirrung, M.C.; Morehead, A.T.; Young, B.G. The Total Synthesis of Natural Products: Bicyclic and Tricyclic Sesquiterpenes; John Wiley \& Sons: Atlanta, GA, USA, 2009.

5. Overton, K.H. Terpenoids and Steroids; RSC Publishing: London, UK, 1975.

6. Kornprobst, J.-M. Encyclopedia of Marine Natural Products; Wiley-Blackwell: Oxford, UK, 2010. 
7. $\quad$ Bideau, F.L.; Kousara, M.; Chen, L.; Wei, L.; Dumas, F. Tricyclic Sesquiterpenes from Marine Origin. Chem. Rev. 2017, 117, 6110-6159. [CrossRef]

8. Mayer, A.M.S.; Rodríguez, A.D.; Taglialatela-Scafati, O.; Fusetani, N. Marine Pharmacology in 2009-2011: Marine Compounds with Antibacterial, Antidiabetic, Antifungal, Anti-Inflammatory, Antiprotozoal, Antituberculosis, and Antiviral Activities; Affecting the Immune and Nervous Systems, and other Miscellaneous Mechanisms of Action. Mar. Drugs 2013, 11, $2510-2573$.

9. Wright, A.D.; König, G.M.; Angerhofer, C.K.; Greenidge, P.; Linden, A.; Desqueyroux-Faundez, R. Antimalarial Activity: The Search for Marine-Derived Natural Products with Selective Antimalarial Activity. J. Nat. Prod. 1996, 59, 710-716. [CrossRef] [PubMed]

10. Fraga, B.M. Natural sesquiterpenoids. Nat. Prod. Rep. 1998, 15, 73-92. [CrossRef]

11. Mato, R.; Manzano, R.; Reyes, E.; Carrillo, L.; Uria, U.; Vicario, J.L. Catalytic Enantioselective Transannular Morita-Baylis-Hillman Reaction. J. Am. Chem. Soc. 2019, 141, 9495-9499. [CrossRef] [PubMed]

12. Tran, D.N.; Cramer, N. Biomimetic Synthesis of (+)-Ledene, (+)-Viridiflorol, (-)-Palustrol, (+)-Spathulenol, and Psiguadial A, C, and D via the Platform Terpene (+)-Bicyclogermacrene. Chem. Eur. J. 2014, 20, 10654-10660. [CrossRef]

13. Barthel, A.; Kaden, F.; Jäger, A.; Metz, P. Enantioselective Synthesis of Guaianolides in the Osmitopsin Family by Domino Metathesis. Org. Lett. 2016, 18, 3298-3301. [CrossRef] [PubMed]

14. Knüppel, S.; Rogachev, V.O.; Metz, P. A Concise Catalytic Route to the Marine Sesquiterpenoids (-)-Clavukerin A and (-)Isoclavukerin A. Eur. J. Org. Chem. 2010, 6145-6148. [CrossRef]

15. Srikrishna, A.; Pardehi, V.H.; Satyanarayana, G. Enantioselective formal total syntheses of Clavukerin A and Isoclavukerin A via a ring-closing metathesis reaction. Tetrahedron Asymmetry 2010, 21, 746-750. [CrossRef]

16. Grimm, E.L.; Methot, J.-L.; Shamji, M. Total synthesis of ( )-Clavukerin A. Pure Appl. Chem. 2003, 75, 231-234. [CrossRef]

17. Friese, J.C.; Krause, S.; Schäfer, H.J. Formal total synthesis of the trinorguaiane sesquiterpenes (+/-)-Clavukerin A and (+/ -)Isoclavukerin. Tetrahedron Lett. 2002, 43, 2683-2685. [CrossRef]

18. Lee, E.; Yoon, C.H. 8-endo Cyclization of (alkoxycarbonyl)methyl radicals: Stereoselective synthesis of (-)-Clavukerin A and (-)-11-hydroxyguaiene. Tetrahedron Lett. 1996, 37, 5929-5930. [CrossRef]

19. Shimizu, I.; Ishikawa, T. Stereoselective synthesis of $( \pm)$-Clavukerin A and ( \pm )-Isoclavukerin A based on palladium-catalyzed reductive cleavage of alkenylcyclopropanes with formic acid. Tetrahedron Lett. 1994, 35, 1905-1908. [CrossRef]

20. Honda, T.; Ishige, H.; Nagase, H. Chiral synthesis of a trinorguaiane sesquiterpene, Clavukerin A. J. Chem. Soc. Perkin Trans 1994, 3305-3310. [CrossRef]

21. Kim, S.K.; Pak, C.S. Total synthesis of (.+-.)-Clavukerin A: A new trinorguaiane sesquiterpene. Biomimetic synthesis of (.+-.)clavularin A from (.+-.)-Clavukerin A. J. Org. Chem. 1991, 56, 6829-6832. [CrossRef]

22. Asaoka, M.; Kosaka, T.; Itahana, H.; Takei, H. Total Synthesis of Clavukerin A and Its Epimer. Chem. Lett. 1991, 1295-1298. [CrossRef]

23. Trost, B.M.; Higuchi, R.I. On the Diastereoselectivity of Intramolecular Pd-Catalyzed TMM Cycloadditions. An Asymmetric Synthesis of the Perhydroazulene (-)-Isoclavukerin A. J. Am. Chem. Soc. 1996, 118, 10094-10105. [CrossRef]

24. Huang, A.-C.; Sumby, C.J.; Tiekink, E.R.T.; Taylor, D.K. Synthesis of guaia-4(5)-en-11-ol, guaia-5(6)-en-11-ol, aciphyllene, 1-epimelicodenones $\mathrm{C}$ and $\mathrm{E}$, and other guaiane-type sesquiterpenoids via the diastereoselective epoxidation of guaiol. J. Nat. Prod. 2014, 77, 2522-2536. [CrossRef] [PubMed]

25. Rienäcker, R.; Graefe, J. Catalytic Transformations of Sesquiterpene Hydrocarbons on Alkali Metal/Aluminum Oxide. Angew. Chem. Int. Ed. Engl. 1985, 24, 320-321. [CrossRef]

26. Wang, Y.; Darweesh, A.F.; Zimdars, P.; Metz, P. An efficient synthesis of the guaiane sesquiterpene (-)-isoguaiene by domino metathesis. Belstein J. Org. Chem. 2019, 15, 858-862. [CrossRef]

27. Blay, G.; Garcia, B.; Molina, E.; Pedro, J.R. Total Syntheses of Four Stereoisomers of $4 \alpha$-Hydroxy- $1 \beta, 7 \beta$-peroxy- $10 \beta H$-guaia-5-ene. Org. Lett. 2005, 7, 3291-3294. [CrossRef]

28. Sasaki, S.; Sutoh, K.; Shimizu, Y.; Kato, K.; Yoshifuji, M. Oxidation of tris(2,4,6-triisopropylphenyl)phosphine and arsine Tetrahedron Lett. 2014, 55, 322-325. [CrossRef]

29. Hilliard, C.R.; Bhuvanesh, N.; Gladysz, J.A.; Blümel, J. Synthesis, purification, and characterization of phosphine oxides and their hydrogen peroxide adducts. Dalton Trans. 2012, 41, 1742-1754. [CrossRef] [PubMed]

30. Bhattacharyya, P.; Slawin, A.M.Z.; Smith, M.B.; Woolins, J.D. Palladium(II) and Platinum(II) Complexes of the Heterodifunctional Ligand $\mathrm{Ph}_{2} \mathrm{PNHP}(\mathrm{O}) \mathrm{Ph}_{2}$. Inorg. Chem. 1996, 35, 3675-3682. [CrossRef]

31. Whitaker, C.M.; Kott, K.L.; McMahon, R.J. Synthesis and Solid-State Structure of Substituted Arylphosphine Oxides. J. Org. Chem. 1995, 60, 3499-3508. [CrossRef]

32. Relles, H.M.; Schluenz, R.W. Chemical Transformations with Regenerable, Polymer-Supported Trisubstituted Phosphine Dichlorides. Efficacious Incorporation of Phosphorus Reagents on Polymer Supports. J. Am. Chem. Soc. 1974, 96, 6469-6475. [CrossRef]

33. Kociensky, P.J. Protecting Groups; Thieme: Stuttgart, Germany, 2005.

34. Wuts, P.G.M.; Greene, T.W. Protective Groups in Organic Synthesis; Wiley: Hoboken, NJ, USA, 2007.

35. Kerwin, S.M.; Paul, A.G.; Heathcock, C.H. Quassinoid synthesis. 2. Preparation of a tetracyclic intermediate having the bruceantin tetrahydrofuran ring. J. Org. Chem. 1987, 52, 1686-1695. [CrossRef]

36. Kumar, J.S.R.; O'Sullivan, M.; Resiman, S.E.; Hulford, C.A.; Ovaska, T.V. Facile approach to the bicyclo[5.3.0]decane ring system; efficient synthesis of ( \pm )-7-epi- $\beta$-bulnesene. Tetrahedron Lett. 2002, 43, 1939-1941. [CrossRef] 
37. Banwell, M.G.; Hockless, D.C.R.; McLeod, M.D. Chemoenzymatic total syntheses of the sesquiterpene (-)-patchoulenone. New J. Chem. 2003, 27, 50-59. [CrossRef]

38. Bertz, S.H.; Miao, G.; Rossiter, B.E.; Snyder, J.P. New Copper Chemistry. 25. Effect of TMSCl on the Conjugate Addition of Organocuprates to alpha.-Enones: A New Mechanism. J. Am. Chem. Soc. 1995, 117, 11023-11024. [CrossRef]

39. Reuss, R.H.; Hassner, A. Synthetic methods. IV. Halogenation of carbonyl compounds via silyl enol ethers. J. Org. Chem. 1974, 39, 1785-1787. [CrossRef]

40. Jeganathan, A.; Richardson, S.K.; Watt, D.S. Manganese Triacetate Oxidation of 3 $\beta$, 3a $\beta, 6$-Trimethyl-3a, 7a $\beta$-dihydro-2(3H), 5(4H)-benzofurandione. Synth. Commun. 1989, 19, 1091-1100. [CrossRef]

41. Roosen, P.C.; Vanderwal, C.D. Investigations into an Anionic Oxy-Cope/Transannular Conjugate Addition Approach to 7,20Diisocyanoadociane. Org. Lett. 2014, 16, 4368-4371. [CrossRef] [PubMed]

42. Hashimoto, S.; Katoh, S.-I.; Kato, T.; Urabe, D.; Inoue, M. Total Synthesis of Resiniferatoxin Enabled by Radical-Mediated Three-Component Coupling and 7-endo Cyclization. J. Am. Chem. Soc. 2017, 139, 16420-16429. [CrossRef] [PubMed]

43. Shenvi, R.A.; Guerrero, C.A.; Shi, J.; Li, C.-C.; Baran, P.S. Synthesis of (+)-cortistatin A. J. Am. Chem. Soc. 2008, 130, 7241-7243. [CrossRef] [PubMed]

44. Ikawa, T.; Hattori, K.; Sajiki, H.; Hirota, K. Solvent-modulated Pd/C-catalyzed deprotection of silyl ethers and chemoselective hydrogenation. Tetrahedron 2004, 60, 6901-6911. [CrossRef]

45. Mahoney, W.S.; Brestensky, D.M.; Stryker, J.M.J. Selective hydride-mediated conjugate reduction of .alpha.,.beta.-unsaturated carbonyl compounds using [(Ph3P)CuH]6. Am. Chem. Soc. 1988, 110, 291. [CrossRef]

46. Meiries, S.; Bartoli, A.; Decostanzi, M.; Parrain, J.-L.; Commeiras, L. Directed studies towards the total synthesis of (+)-13deoxytedanolide: Simple and convenient synthesis of the C8-C16 fragment. Org. Biomol. Chem. 2013, 11, 4882-4890. [CrossRef]

47. Ojima, I.; Kogure, T. Reduction of carbonyl compounds via hydrosilylation. 4. Highly regioselective reductions of. alpha.,. beta.-unsaturated carbonyl compounds. Organometallics 1982, 1, 1390-1399. [CrossRef]

48. Ito, H.; Ishizuka, T.; Arimoto, K.; Miura, K.; Hosomi, A. Generation of a reducing reagent from copper (I) salt and hydrosilane. New practical method for conjugate reduction. Tetrahedron Lett. 1997, 38, 8887-8890. [CrossRef]

49. Miller, R.D.; McKean, D.R. The Facile Silylation of Aldehydes and Ketones using Trimethylsilyl Iodide: An Exceptionally Simple Procedure for the Generation of Thermodynamically Equilibrated Trimethylsilylenol Ethers. Synthesis 1979, 730-732. [CrossRef]

50. Ryu, I.; Murai, S.; Niwa, I.; Sonoda, N. A Convenient Synthesis of $\alpha$-Phenylseleno Ketones and Aldehydes from Enol Silyl Ethers and Phenylselenenyl Bromide. Synthesis 1977, 12, 874-876. [CrossRef]

51. Kamikubo, T.; Ogasawara, K. Preparation of (+)-Tricyclo[6.2.1.02,7]undec-2(7)-en-3-one and Its Conversion into (+)-epi- $\beta$-Santalene. Chem. Lett. 1995, 2, 95-96. [CrossRef]

52. Fernández, B.; Pérez, J.A.M.; Granja, J.R.; Castedo, L.; Mouriño, A. Synthesis of hydrindan derivatives related to vitamin D. J. Org. Chem. 1992, 57, 3173-3178. [CrossRef]

53. Sharpless, K.B.; Younh, M.W.; Lauer, R.F. Reactions of selenoxides: Thermal syn-elimination and $\mathrm{H}_{2}{ }^{18} \mathrm{O}$ exchange. Tetrahedron Lett. 1973, 22, 1979-1982. [CrossRef]

54. Sharpless, K.B.; Lauer, R.F.; Teranishi, A.Y. Electrophilic and nucleophilic organoselenium reagents. New routes to .alpha.,.beta.unsaturated carbonyl compounds. J. Am. Chem. Soc. 1973, 95, 6137-6139. [CrossRef]

55. Reich, H.J.; Renga, J.M.; Reich, I.L. Organoselenium chemistry. Conversion of ketones to enones by selenoxide syn elimination. J. Am. Chem. Soc. 1975, 97, 5434-5447. [CrossRef]

56. Angeles, A.R.; Waters, S.P.; Danishefsky, S.J. Total Syntheses of (+)- and (-)-Peribysin E. J. Am. Chem. Soc. 2008, 130, 13765-13770 [CrossRef]

57. Uchida, K.; Yokoshima, S.; Kan, T.; Fukuyama, T. Total Synthesis of ( \pm )-Morphine. Org. Lett. 2006, 8, 5311-5313. [CrossRef]

58. Hu, X.-D.; Tu, Y.Q.; Zhang, E.; Gao, S.; Wang, S.; Wang, A.; Fan, C.-A.; Wang, M. Total Synthesis of ( \pm )-Galanthamine. Org. Lett. 2006, 8, 1823-1825. [CrossRef] [PubMed]

59. Ito, Y.; Hirao, T.; Saegusa, T. Synthesis of .alpha.,.beta.-unsaturated carbonyl compounds by palladium(II)-catalyzed dehydrosilylation of silyl enol ethers. J. Org. Chem. 1978, 43, 1011-1013. [CrossRef]

60. Tanemura, K.; Suzuki, T.; Nishida, Y.; Satsumabayashi, K.; Horaguchi, T. A mild and efficient procedure for $\alpha$-bromination of ketones using N-bromosuccinimide catalysed by ammonium acetate. Chem. Commun. 2004, 470-471. [CrossRef] [PubMed]

61. Ushakov, D.B.; Navickas, V.; Ströbele, M.; Maichle-Mössmer, C.; Sasse, F.; Maier, M.E. Total Synthesis and Biological Evaluation of (-)-9-Deoxy-englerin A. Org. Lett. 2011, 13, 2090-2093. [CrossRef] [PubMed]

62. Gijsen, H.J.M.; Wijnberg, J.B.P.A.; Stork, G.A.; Groot, A. The synthesis of (-)-kessane, starting from natural (+)-aromadendrene-II. Tetrahedron 1991, 47, 4409-4416. [CrossRef]

63. Armarego, W.L.F.; Chai, C.L.L. Purification of Laboratory Chemicals, 7th ed.; Elsevier: Oxford, UK, 2012.

64. Williams, D.B.G.; Lawton, M. Drying of Organic Solvents: Quantitative Evaluation of the Efficiency of Several Desiccants. J. Org. Chem. 2010, 75, 8351-8354. [CrossRef]

65. Still, W.C.; Kahn, H.; Mitra, A.J. Rapid chromatographic technique for preparative separations with moderate resolution. J. Org. Chem. 1978, 43, 2923-2925. [CrossRef] 